\title{
Daniels, J. (2021) Gun/Shy. Wayne State University Press.
}

\section{Review by William DeGenaro}

Jim Daniels has been a working poet for upwards of forty years, perhaps known best to readers of The Journal of Working-Class Studies for his earliest collections and chapbooks. These early works drew on his experience growing up the son of a Michigan autoworker. His fantastic 1990 volume Punching Out, for instance, consists of a cycle of poems about Digger, a young man whose father gets him a job on the assembly line, initially as a summer gig. We witness Digger learning the ropes, becoming acclimated to factory norms, joining the UAW, and eventually becoming a lifer at 'Ford's.'

In these early poems, Daniels used vivid and precise markers of Warren, Michigan, most prominently its car factories but also its burger stands and bars, its trajectory from Democratic stronghold to home of the 'Reagan Democrat,' and its proximity to Detroit and the racial dividing line of 8 Mile Road. Before there was Eminem, there was Jim Daniels.

For much of his four-decade career, Daniels has also taught creative writing in Pittsburgh, and his experiences learning the middle-class conventions of academe have provided compelling material for his accessible, often-autobiographical brand of free-verse poetry. One of Daniels' abiding themes has been the complex range of emotions triggered by straddling two different worlds. Poet

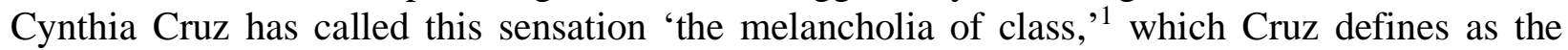
wonder, confusion, alienation, and guilt that accompanies growing up working class but moving into a middle-class world.

Daniels' explorations of that theme and that affective state have fed a prolific career as a poet (over two dozen books and chapbooks), editor, occasional fiction and screenplay writer, and frequent reader and speaker at working-class studies conferences.

In his newest collection of poetry, Gun/Shy, Daniels offers perhaps his most evenly balanced look at the two very specific worlds he's inhabited. Indeed, about half of the book's fifty-two poems exist in the world of 1960s/1970s working-class suburban Detroit, and the other half take place in the world of contemporary, middle-class suburbia. Poems existing in the latter world are particularly interesting when considered in the context of Daniels' broader body of work. In the more contemporary poems, Daniels sustains attention on the aforementioned straddling of class lines - long a concern of his poetry - but also allows his work to drift toward new shores like reflections on caring for senior parents and beginning to confront one's own mortality.

Similarly, these present-day poems deepen the resonance of the poems in Gun/Shy that are about childhood and adolescence back in Michigan. Both sets of poems in the collection seem to have the same, seemingly autobiographical narrator at two different points in his life. And there is much

\footnotetext{
${ }^{1}$ See Cruz, C. (2021) The Melancholia of Class: A Manifesto for the Working Class. Repeater.
} 
symmetry between the 60s/70s poems and the contemporary poems beyond that consistent narrative voice. Daniels juxtaposes snapshots of his narrator sneaking a joint behind his parents' backs with snapshots of his narrator fifty years later caring for those parents once they're infirmed. In one poem, our narrator is home sick, cartoons on the television, watching his mom mending clothes on her sewing machine. A few pages later, that same narrator is taking his parents to have a will drawn up. The narrative that emerges is both compelling and focused. Gun/Shy is a satisfying read, even when presenting unsettling realities.

Daniels frequently juxtaposes images of childhood and adolescence in the two milieus at the heart of Gun/Shy's narrative, allowing a rich paradox to emerge. The pains of growing up are in some ways consistent across the working-class and middle-class contexts, but that angst is experienced differently due to real and impactful material conditions. In 'The New Math,' Daniels' narrator describes watching movies with his daughter:

...When I was a kid, we had no

futons or streaming. But we had guardian angels

and undisputed national champions.

Okay, your dad's a fibber...

The speaker in the poem is aware of the small moments as well as the small markers signifying generational and class divide. Elsewhere in Gun/Shy, that speaker takes his kids snorkeling and to museums and on vacations, while remembering his own youth working in a party store, smoking behind the garage, eating his mom's 'hamburger surprise.' Daniels never preaches and never draws universal conclusions, preferring instead to document difference. But again, the paradox is that for all the contrastive imagery of working- vs. middle-class family life there are many shared experiences too. Take for example 'Poison Control,' where we learn that a childhood friend of the narrator and the narrator's own son both struggled with similar mental health issues. There are adolescent pains in Gun/Shy informed by social class and there are adolescent pains that transcend class divides.

Nor is class the only factor informing the lived experiences and emotional vulnerabilities of the characters we encounter in Gun/Shy. Indeed, the narrator's youth and adolescence are marked by working-class identity but also social and political context (including the Detroit uprisings of 1967, which looms large in several poems in the collection), substance abuse, and familial love. And the narrator's parental perspective is informed by his class mobility but also generational dynamics, region and geography, and much more. Interestingly, few poems focus on the workplace; instead, home life is in the foreground. If Punching Out was an ode to the factory floor, the $60 \mathrm{~s} / 70 \mathrm{~s}$ poems in Gun/Shy are odes to a paneled basement, classic rock on the stereo, and a hint of weed in the air.

Few poems in the collection engage with the period of time between the narrator's teen years and the present day. The book's narrative jumps back and forth between the Vietnam era and the Trump era with very few mentions of the intervening decades. Readers are left to make inferences about those decades. One of the few exceptions is a terrific poem that appears late in the collection, 'The Secret Agent Briefcase,' in which the narrator recalls his entry into academe: 
When I got my professor gig, my parents bought me a narrow hard-sided briefcase with a combination lock. You could sit on it. Stand in principle on it. Smack it upside your head to get your smarts going. You could not squeeze many books into it...

...I carried it to school

My first fall until a colleague joked

You got a bomb in there? ...

The narrator eventually stashes the briefcase in the back of his closet, aware of the ways it marks him as different. I won't reveal the briefcase's ultimate fate, but suffice to say the poem's conclusion both illustrates and complicates the briefcase as a performative prop.

Gun/Shy has a great deal to offer those new to the poetry of Jim Daniels as well as those who have followed his work for many years. It is both another entry in his series of reflections on class, work, and family, as well as a signal that his work is tackling new milieus and themes, most notably mortality. Another memorable poem from late in the collection, 'Tying My Show at the New Pornographers Concert,' places the narrator at a contemporary indie rock concert, enjoying the show while also 'looking for someone my age.' He writes, 'I'm 59, going on whatever's next.' Readers of Gun/Shy will definitely find themselves eager to find out what's next for Daniels and his still-engaging poetry.

\section{Reviewer Bio}

William DeGenaro is Professor of Composition \& Rhetoric at the University of Michigan Dearborn where he teaches composition and creative writing. He's served Fulbright Fellowships in Lebanon and Jordan and his scholarly work on composition pedagogy, academic serving learning, and working-class rhetorics has appeared in journals including Rhetoric Review, Journal of Basic Writing, and WPA: Writing Program Administration. 